\section{Androgen and Glucocorticoid Receptors in Rat Skeletal Muscle*}

\section{ERIK DAHLBERG, MAREK SNOCHOWSKI and JAN-ÅKE GUSTAFSSON}

\author{
Departments of Chemistry and Medical Nutrition, \\ Karolinska Institutet, Fack, S-104 01 Stockholm 60, \\ Sweden
}

Glucocorticoids have recently been shown to possess specific receptor proteins in skeletal muscle, but whether this tissue also contains androgen receptors is still a matter of debate. ${ }^{1}$ Testosterone and methyltrienolone (a synthetic androgen) bound to skeletal muscle cytosol with high affinity and low capacity, ${ }^{2-4}$ but the binding of $5 \alpha$-dihydrotestosterone (DHT) was of low affinity ${ }^{3,4}$ or could be displaced by estradiol-17 $\beta .^{2}$ Subsequently DHT was reported to bind not as such but after reduction of its 3-oxo function. ${ }^{5}$ It was thus of interest to investigate whether or not this tissue contains receptors for steroid hormones, and to that end synthetic ${ }^{3} \mathrm{H}$-labelled steroids were used. Androgen and glucocorticoid receptors were detected using methyltrienolone (17 $\beta$-hydroxy-17 $\alpha$-methyl-4,9,11estratrien-3-one) ${ }^{6}$ and dexamethasone ( $9 \alpha$-fluoro$11 \beta, 17 \alpha, 21$-trihydroxy-16 $\alpha$-methyl-1,4-pregnadiene3,20 -dione), ${ }^{7}$ respectively. Attempts to detect estrogen and progestin receptors were made using R 2858 $(11 \beta \text {-methoxy-17 } \alpha \text {-ethynyl-estradiol-17 } \beta)^{8}$ and $\mathbf{R}$ 5020 (17 $\alpha, 21$-dimethyl-19-nor-4,9-pregnadiene-3,20dione), ${ }^{9}$ respectively.

Experimental. Cytosol was prepared from male rats 2 to 3 weeks after castration by centrifugation at $105000 \mathrm{~g}$ for $1 \mathrm{~h}$ of a homogenate of muscle tissue (1:1 tissue to buffer ratio $(50 \mathrm{mM}$ Tris- $\mathrm{HCl}, \mathrm{pH} \cdot 7.4$, $1 \mathrm{mM}$ EDTA, $0.1 \mathrm{mM}$ dithioerythritol, $10 \%$ glycerol)). DNA was measured in the pellets by a modified Burton method ${ }^{10,11}$ and protein in the supernatant (cytosol) by a modified version of the method of Lowry et al. ${ }^{12}$ In preliminary experiments we found no high-affinity low-capacity binding of the estrogen $R 2858$ or the progestin R 5020, but the binding of methyltrienolone and dexamethasone was of receptor-like character. Hence attempts were made to characterize the binding of the latter two steroids in muscle cytosol. Subsequently, however, estrogen receptors have been detected, and their characterization will be described elsewhere.

Binding kinetics were studied by incubation of $0.2 \mathrm{ml}$ portions of cytosol with $0.1 \mathrm{ml}$ buffer

\footnotetext{
* Communication at the Meeting of the Swedish Biochemical Society in Stockholm, 29th November, 1979.
}

solution of steroid ligand at six concentrations (either 0.07 to $2 \mathrm{nM}{ }^{3} \mathrm{H}$-methyltrienolone plus a 100 -fold molar excess of dexamethasone or 0.4 to $15 \mathrm{nM}{ }^{3} \mathrm{H}$-dexamethasone (final concentrations)) at 0,15 and $23{ }^{\circ} \mathrm{C}$ for various periods of time up to $40 \mathrm{~h}\left(0\right.$ and $\left.15^{\circ} \mathrm{C}\right)$ or up to $10 \mathrm{~h}\left(23^{\circ} \mathrm{C}\right)$ until terminated by the addition of $0.4 \mathrm{ml}$ of a suspension of charcoal $(0.625 \%)$ and dextran T70 $(0.0625 \%)$ in the homogenization buffer. The dextran-coated charcoal treatment was carried out at $0-4{ }^{\circ} \mathrm{C}$ for $20 \mathrm{~min}$, and after centrifugation at $1000 \mathrm{~g}$ for $5 \mathrm{~min}$, $0.5 \mathrm{ml}$ supernatant was taken for determination of radioactivity. Non-specific binding was estimated from similar incubations that in addition contained a 100-fold excess of unlabelled ligand, and the total amount of radioactivity present during incubation was determined from incubations where the cytosol and dextran-coated charcoal were substituted with buffer. Dissociation was determined separately at each temperature by addition of a 1000-fold excess of unlabelled ligand after the formation of ligandreceptor complexes for $20 \mathrm{~h}$ at $0{ }^{\circ} \mathrm{C}$. All incubations were carried out in duplicate. Calculation of kinetic parameters was performed as described elsewhere. ${ }^{1}$

Conditions close to equilibrium were obtained after 15 to $25 \mathrm{~h}$ of incubation at $0{ }^{\circ} \mathrm{C}$ for both ligands, and were used for saturation analysis. Calculation of equilibrium binding data was carried out according to Scatchard from data corrected for non-specific binding. ${ }^{13}$ The calculation of equilibrium data are described in detail elsewhere. ${ }^{1}$

The ligand specificities of the ${ }^{3} \mathrm{H}$-dexamethasone and the ${ }^{3} \mathrm{H}$-methyltrienolone binding sites were studied by incubation of $0.2 \mathrm{ml}$ portions of cytosol with $0.1 \mathrm{ml}$ buffer solution of $2 \mathrm{nM}{ }^{3} \mathrm{H}$-methyltrienolone or $15 \mathrm{nM}^{3} \mathrm{H}$-dexamethasone (final concentrations) plus $10 \mu \mathrm{l}$ ethanolic solution of competitor (to yield final concentrations of competitor of $1-128 \mathrm{nM}$ or $8-1024 \mathrm{nM}$ in the cases of ${ }^{3} \mathrm{H}$ methyltrienolone or ${ }^{3} \mathrm{H}$-dexamethasone, respectively) for $24 \mathrm{~h}$ at $0-4{ }^{\circ} \mathrm{C}$. Total binding (specific plus non-specific) was determined from incubations containing cytosol and ${ }^{3} \mathrm{H}$-labelled ligand, but where the ethanolic solution of competitor was replaced by vehicle alone. Non-specific binding was determined from incubations containing the highest dose of competitor, cytosol and ${ }^{3} \mathrm{H}$-labelled ligand, additionally a 100 -fold excess of unlabelled ligand. Unbound and protein-bound steroids were separated by dextran-coated charcoal treatment as described above, and the calculation of relative binding affinity (RBA)(defined as the ratio between the concentration of ligand and that of competitor required to obtain $50 \%$ displacement of ${ }^{3} \mathrm{H}$-ligand from its receptor binding site) performed from plots of logit $y$ against log concentration of competitor ${ }^{14}$ as described elsewhere. ${ }^{1,15}$ Logit $y=\ln$ (specific binding in the presence of a given concentration of 
competitor divided by that without any competitor).

The metabolism of methyltrienolone, testosterone and $5 \alpha$-dihydrotestosterone in rat muscle cytosol was studied by incubation of $0.2 \mathrm{ml}$ cytosol with 0.1 $\mathrm{ml}$ buffer solution of ${ }^{3} \mathrm{H}$-labelled steroid (10 nM final concentration) at 0,21 and $37^{\circ} \mathrm{C}$ for various periods of time up to $20 \mathrm{~h}$ until extracted twice with water-saturated ethyl acetate containing non-radioactive standard steroids, and the extracts were chromatographed on silica gel thin layer plates. To yield sufficient quantities of product for identification of metabolites, $1 \mathrm{ml}$ cytosol was incubated with ${ }^{14} \mathrm{C}$-labelled $5 \alpha$-dihydrotestosterone $(25 \mu \mathrm{M}$ final concentration) (the only steroid that was metabolized) at $37^{\circ} \mathrm{C}$ for $1 \mathrm{~h}$, and the product peak from the TLC plate analyzed using computerized gas chromatography-mass spectrometry after trimethylsilylation as described elsewhere. ${ }^{1}$

Chromatography on DNA-cellulose, gel exclusion chromatography on Sephadex G-150 and preparative electrofocusing of steroid-receptor complexes were carried out ad described elsewhere. ${ }^{1}$

Results and discussion. The rates of association and degradation of the dexamethasone-'and methyltrienolone-receptor complexes were highly dependent on temperature (activation energies of 61 and $54 \mathrm{~kJ} \mathrm{~mol}^{-1}$ for second-order association rates and -72 and $-108 \mathrm{~kJ} \mathrm{~mol}^{-1}$ for first-order degradation rates of dexamethasone- and methyltrienolonereceptor complexes, respectively), i.e. the temperature-dependence of association was greater in the case of dexamethasone, and that of degradation was greater in the case of methyltrienolone. At all temperatures the separately determined dissociation was insignificant compared to association and degradation. Estimates of the rate constants are given in Table 1.
Saturation analyses at conditions close to equilibrium showed that the binding of the two steroids was saturable, and Scatchard analysis gave apparent equilibrium dissociation constants $\left(K_{d}\right)$ for dexamethasone and methyltrienolone of about 7 and 0.3 $\mathrm{nM}$, respectively, corresponding to free energy changes of about -41 and $-49 \mathrm{~kJ} \mathrm{~mol}^{-1}$ at $0{ }^{\circ} \mathrm{C}$. Since the $K_{\mathrm{d}}$ values did not change appreciably with temperature, enthalpies did not contribute significantly to the free energy changes, and hence these were largely made up from temperature and entropy, indicating that the binding of steroids was hydrophobic in nature. ${ }^{16}$ The apparent equilibrium maximum number of binding sites were about 1900 femtomol/g tissue, 3500 femtomol/mg DNA or 30 femtomol/mg protein in the case of the dexamethasone receptor. The corresponding values for the methyltrienolone receptor were about 100 femtomol/g tissue, 200 femtomol/mg DNA or 2 femtomol/mg protein.

The efficiency of various steroids as competitors for the specific ${ }^{3} \mathrm{H}$-dexamethasone binding sites were in decreasing order of potency (RBA values in parenthesis): triamcinolone acetonide ( $9 x$-fluoro$11 \beta, 21$-dihydroxy-16 $\alpha, 17 \alpha[$ (methylethylidene)bis(oxy)]-1,4-pregnadiene-3,20-dione) $(0.54)$, corticosterone $(0.46)$, cortisol $(0.11)$, progesterone $(0.09)$, methyltrienolone $(0.06)$, estradiol-17 $\beta(0.01)$. The following compounds had RBA values below 0.01 for specific ${ }^{3} \mathrm{H}$-dexamethasone binding sites: 19-nortestosterone, testosterone, $5 \alpha$-dihydrotestosterone, 19-nortestosterone decanoate (19-nor-4-androsten-3-one$17 \beta$-yl decanoate), G 302 (2-formyl-11 $\beta, 17 \beta$-dihydroxy-17 $\alpha$-methyl-1,4-androstadien-3-one), BR 906 (11 $\beta, 17 \beta$-dihydroxy-17 $\alpha$-methyl-1,4-androstadien-3 one-2-carboxylic acid), BR $917(11 \beta, 17 \beta$-dihydroxy$17 \alpha$-methyl-1,4-androstadien-3-one-2-carboxylic

Table 1. Kinetic constants for the binding of ${ }^{3} \mathrm{H}$-dexamethasone and ${ }^{3} \mathrm{H}$-methyltrienolone in cytosol from rat skeletal muscle. Negative sign indicates decreased specific binding, and n.d. not determined.

\begin{tabular}{lccc}
\hline $\begin{array}{l}\text { Type of rate constant } \\
\text { (unit) }\end{array}$ & $\begin{array}{l}\text { Temp. } \\
{ }^{\circ} \mathrm{C}\end{array}$ & $\begin{array}{l}\text { Rate constant } \\
\text { Dexamethasone }\end{array}$ & $\begin{array}{l}\text { Rate constant } \\
\text { Methyltrienolone }\end{array}$ \\
\cline { 2 - 3 } & 0 & $3.4 \times 10^{6}$ & $1.4 \times 10^{8}$ \\
Association $\left(\mathrm{M}^{-1} \mathrm{~h}^{-1}\right)$ & 15 & $1.4 \times 10^{7}$ & $5.0 \times 10^{8}$ \\
& 23 & $2.7 \times 10^{7}$ & $9.0 \times 10^{8}$ \\
& 0 & & $3.3 \times 10^{-3}$ \\
Degradation $\left(\mathrm{h}^{-1}\right)$ & 15 & $-2.5 \times 10^{-2}$ & $-1.8 \times 10^{-2}$ \\
& 23 & $-1.1 \times 10^{-1}$ & $-1.6 \times 10^{-1}$ \\
& 0 & $-4.1 \times 10^{-1}$ & $-9.9 \times 10^{-3}$ \\
Dissociation $\left(\mathrm{h}^{-1}\right)$ & 15 & $-1.2 \times 10^{-1}$ & $n . d$. \\
& 23 & $-2.5 \times 10^{-1}$ & $-2.9 \times 10^{-1}$ \\
\hline
\end{tabular}


acid decyl ester) and stanozolol (17 $\alpha$-methyl-5 $\alpha$ androstano- $[3,2-c]$ pyrazol-17 $\beta$-ol).

The efficiency of competitors for specific ${ }^{3} \mathrm{H}$ methyltrienolone binding sites were: 19 -nortestosterone $(0.47)$, testosterone $(0.15)$, stanozolol $(0.08)$, estradiol-17 $\beta(0.04)$, progesterone $(0.03)$. The following compounds had RBA values of less than 0.01 : 19-nortestosterone decanote, dexamethasone, $5 \alpha$ androstane-3,17-dione, $5 \alpha$-androstane- $3 \alpha, 17 \beta$-diol, triamcinolone acetonide, $5 \alpha$-dihydrotestosterone, G 302, BR 906, and BR 917.

Since $5 \alpha$-dihydrotestosterone was inefficient when used as a competitor for specific ${ }^{3} \mathrm{H}$-methyltrienolone binding sites, the metabolism of this steroid and of testosterone and methyltrienolone in rat muscle cytosol was studied. Whereas the latter two steroids were not metabolized by muscle cytosol, silica gel thin layer chromatography revealed the formation of one radioactive peak formed from $5 \alpha$-dihydrotestosterone, and this peak was corresponding to that of $5 \alpha$-androstane- $3 \alpha, 17 \beta$-diol and $5 \alpha$-androstane- $3 \beta, 17 \beta$-diol (not separated by the solvent system). These two isomers were identified by gas chromatography-mass spectrometry as the products of DHT metabolism by muscle cytosol, and were formed to $86 \%$ (the $3 \alpha$-isomer) and $14 \%$ (the $3 \beta$-isomer). The conversion of $5 \alpha$-dihydrotestosterone was rapid even at low temperature (20 min half-life at $0^{\circ} \mathrm{C}$ ) and without cofactors, and proceeded with an activation energy of about 34 $\mathrm{kJ} \mathrm{mol}^{-1}$.

Both the dexamethasone- and the methyltrienolone-receptor complexes were retained by DNA when chromatographed on DNA-cellulose columns after a prior cellulose column, and were eluted by $\mathrm{NaCl}$ at an ionic strength of about 0.1 . The DNAcellulose step gave about 20 times purification on a protein basis, and was used as a prior step to gel exclusion chromatography and electrofocusing. Both receptor complexes were excluded from Sephadex G-150, possibly due to formation of molecular aggregates. Electrofocusing in a preparative $(110 \mathrm{ml})$ LKB column gave reproducible patterns of three peaks for each receptor. The apparent $\mathrm{pI}$ values for these peaks were 5.4, 5.6 and 6.2 (glucocorticoid receptor) and 5.9, 6.2 and 8.5 (androgen receptor).

In conclusion, kinetic and thermodynamic evidence showed marked differences between the dexamethasone and the methyltrienolone binding sites in skeletal muscle. The data obtained for methyltrienolone agrees well with the data reported for the androgen receptor in male rat reproductive organs. ${ }^{17}$ The ligand specificity of the high affinity low capacity binding sites for methyltrienolone in muscle cytosol is typical of an androgen receptor ${ }^{18}$ and that of the specific dexamethasone binding sites is typical of a glucocorticoid receptor. ${ }^{19}$ The apparent inability of $5 \alpha$-dihydrotestosterone to compete with specific ${ }^{3} \mathrm{H}$-methyltrienolone binding sites may have been due to the rapid and efficient metabolism of this compound by muscle cytosol.

The properties of the androgen and glucocorticoid receptors closely resemble those in male rat reproductive organs and rat liver, respectively. It hence appears valid to characterize skeletal muscle as a target organ for both these hormones.

1. Snochowski, M., Dahlberg, E. and Gustafsson, J.-Å. Biochemistry (1979). Submitted for publication.

2. Michel, G. and Baulieu, E.-E. C. R. Acad. Sci. Ser. D 279 (1974) 421.

3. Tremblay, R. R., Dubé, J. Y., Ho-Kim, M. A. and Lesage, R. Steroids 29 (1977) 185.

4. Dubé, J. Y., Tremblay, R. R. and Chapdelaine, P. Horm. Res. 7 (1976) 333.

5. Dionne, F. T., Dubé, J. Y. and Tremblay, R. R. Can. J. Biochem. 55 (1977) 995.

6. Bonne, C. and Raynaud, J.-P. Steroids 26 (1975) 227.

7. Baxter, J. D. and Tomkins, G. M. Proc. Natl. Acad. Sci. U.S.A. 65 (1970) 709.

8. Raynaud, J.-P., Mercier-Bodard, C. and Baulieu, E.-E. Steroids 18 (1971) 767.

9. Philibert, D. and Raynaud, J.-P. Steroids 22 (1973) 89.

10. Giles, K. W. and Myers, A. Nature (London) 206 (1965) 93.

11. Richards, G. M. Anal. Biochem. 57 (1974) 369.

12. Peterson, G. L. Anal. Biochem. 83 (1977) 346.

13. Chamness, G. C. and McGuire, W. L. Steroids 26 (1975) 538.

14. Rodbard, D., Rayford, P. L., Cooper, J. A. and Ross, G. T. J. Clin. Endocrinol. Metab. 28 (1968) 1412.

15. Snochowski, M., Dahlberg, E. and Gustafsson, J-Å. Endocrinology (1979). Submitted for publication.

16. Tanford, C. The Hydrophobic Effect, Wiley, New York 1973, p. 1.

17. Wilson, E. M. and French, F. S. J. Biol. Chem. 251 (1976) 5620.

18. Liao, S. In Litwack, G., Ed., Biochemical Actions of Hormones, Academic, New York 1977, Vol. 4, Chapter 8, p. 351.

19. Schmit, J.-P. and Rousseau, G. G. In Baxter, J. D. and Rousseau, G. G., Eds., Glucocorticoid Hormone Action, Springer, Berlin 1979, Chapter 4, p. 79.

Received November 19, 1979. 